\title{
Impact of environmental factors on fish distribution assessed in rangeland streams
}

by Lisa C. Thompson, Larry Forero, Yukako Sado and Kenneth $\mathrm{W}$. Tate

\section{We sampled fish in pools located} on tributaries of Cow Creek in the northern Sacramento Valley, and related fish distribution and habitat use to environmental factors across the 2003 agricultural growing season. This rangeland watershed experiences extensive livestock use, and many landowners divert stream water for pasture irrigation. Our goal was to provide landowners and managers with current baseline information about the conditions in which fish were found. Our results provide a basis for the development and comparison of irrigation best management practices that may improve conditions for native fish in rangeland streams.

$\mathrm{F}$ sh population declines and habitat alteration across Northern California watersheds have resulted in the listing of numerous species under both the state and federal Endangered Species Acts, and instigated the implementation of total maximum daily load (TMDL) water-quality strategies for impaired water bodies. These events have highlighted the importance of species recovery and habitat restoration efforts, while increasing scrutiny of the potential impacts of agricultural practices on cold-water fisheries. Agricultural practices of concern in Northern California watersheds include irrigation diversions, irrigation return flows, riparian grazing and roads.

Restoration and regulatory efforts often adopt a single-variable approach to species recovery. For example, a sediment TMDL is being developed to aid the recovery of coho salmon (Oncorhynchus kisutch) in the Garcia River. To meet the same goal on the south fork of the Trinity River, a stream-

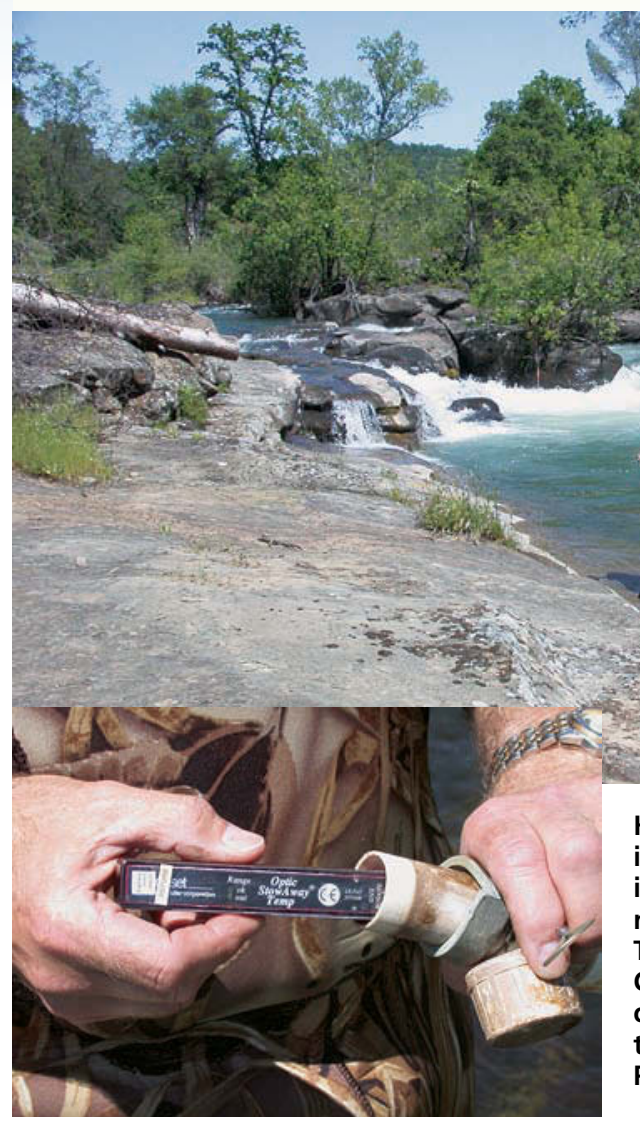

temperature TMDL is being developed. Sediment and stream temperature are both important habitat variables, but a more holistic approach using a suite of interacting habitat and land-use factors would provide listed fish species with a greater chance of recovery. However, few studies have concurrently examined habitat, water quality, fish and agricultural practices. This study of Cow Creek in the northern Sacramento Valley is the first step in such a project for Northern California watersheds. Research on how these factors interact will provide vital information for agricultural management, stream habitat restoration and fisheries recovery planning.

Past land use can be related to the fish communities currently seen in streams (Harding at al. 1998). There is a tendency in some agricultural streams for fish species that depend on streambeds for spawning or foraging to be replaced by species that occupy the water column or are able to clean sediments from their nests. Alternatively, exotic species - such as the bottom-foragers common carp, fathead minnows and catfishes - may invade degraded streams. There is little specific information on the responses of fish in California rangeland streams to land-use practices.

\section{Thermal refugia}

The temperature requirements of salmonids vary with life history stage and by species (Mihursky and Kennedy 1967). Different species have different optimal temperatures for migration, spawning, egg incubation and juvenile growth, and also different lethal-temperature criteria (Beschta et al. 1987; Thompson and Larsen 2004). Since fish are poikilothermic (coldblooded), their metabolic rate and food needs increase with higher water temperatures. If adequate food is not available, fish will lose weight and eventually die, even if temperatures do not reach lethal levels. 


\section{A more holistic approach using a suite of interacting habitat and land-use factors would provide listed fish species with a greater chance of recovery.}

Fish in some Northern California streams are known to use thermally stratified pools as cold-water refugia during hot weather (Nielsen at al. 1994). However, fish may face a tradeoff between temperature and dissolved oxygen in their use of pools. Stratified pools may have cooler temperatures at the bottom, but also lower dissolved-oxygen concentrations with increased depth (Elliott 2000). In addition to pools, fish may seek groundwater-fed locations in order to experience cooler temperatures (Ebersole et al. 2003), but since groundwater may be lower in dissolved oxygen than stream water, fish may still experience stress.

Alternatively, levels of dissolved oxygen in groundwater may be higher than those of stream water depending on how much dissolved oxygen was in the groundwater when it first entered the ground, since dissolved oxygen tends to change little once water goes underground. In their search for appropriate temperature and dissolvedoxygen levels, fish may locate farther from optimal feeding sites, or away from refuges such as large woody de- bris, overhanging banks or rocks. This may result in increased mortality, due to low growth rates and increased vulnerability to size-selective predation, or due to increased predation as fish spend less time in refuges in order to feed (Walters and Juanes 1993). The distribution of fish relative to thermal refugia, and the timing of this use are undocumented for most California rangeland streams, which hampers management efforts to improve fish habitat.

The upper lethal temperature limit for rainbow trout (O. mykiss) is generally thought to be about $75.4^{\circ} \mathrm{F}$ (Beschta et al. 1987). However, Zoellick (1999) found that redband rainbow trout (O. mykiss gairdneri) in southwestern Idaho occupied stream reaches with maximum daily water temperatures of $80.1^{\circ} \mathrm{F}$ to $84.2^{\circ} \mathrm{F}$, and tolerated temperatures above $78.8^{\circ} \mathrm{F}$ for up to 4.4 hours. Flows decreased to 0 cubic feet per second (cfs) in some streams, and some of the streams subsided underground. Despite the low or nonexistent flows, Zoellick observed that pools at the lower ends of the occupied reaches did not show temperature stratification, so

\section{Glossary}

Alevin: A fish that has just hatched from the egg. In the case of salmon and trout, the alevin lives in the gravel at the bottom of the stream until it absorbs its yolk sac and is ready to emerge and begin foraging.

Assemblage: A group of species commonly found together in the same habitat area, such as a stream, lake or estuary. Species within an assemblage may share some habitat preferences, such as water temperature or velocity.

Julian day: The day of the year, from 1 to 365 (366 in a leap year).

Rainbow trout/steelhead: Fish of the species Oncorhynchus mykiss. Rainbow trout live their entire life cycle in freshwater. Steelhead are the anadromous form; they migrate to the ocean to feed and grow, then return to freshwater to spawn.

Refuge: Location (e.g., under a log, rock or undercut bank) where fish can escape from the risk of mortality due to predators such as birds, otters or larger fish.

Refugia: Isolated location in which fish are able to survive during times when most of the surrounding habitat has become unsuitable (e.g., due to high water temperatures).

Thermal stratification: A gradation of temperature, warm to cool, from top to bottom in a pool or lake, that occurs during summer months. Increases in flow or wind may mix the water to an even temperature throughout, disrupting the stratification.

trout were assumed to be experiencing the observed maximum temperatures.

In some cases the downstream limit of trout distribution in these Idaho streams appeared to be limited by unsuitable habitat (e.g., no water or very shallow braided stream channel), but in one case flows and channel conditions appeared to be suitable, so trout may have been limited by temperatures in excess of $84.2^{\circ} \mathrm{F}$. It is not known whether California native fish such as rainbow trout are able to tolerate similar conditions in Central Valley streams. Little is known about the specific temperature tolerances of rainbow trout/steelhead and salmon in the Central Valley. (Rainbow trout and steelhead are the same species, O. mykiss; however, steelhead migrate to the ocean, while rainbow trout spend their entire life cycle in freshwater.)

Myrick and Cech (2004) did a comprehensive review of the published information available for the effects of temperature on juvenile Central Valley Chinook salmon (O. tshawytcha) and steelhead. They looked at survival of eggs, alevin and juveniles, as well as juvenile growth rates, and reported that the number of published studies was "surprisingly low." They reported that survival of eggs declined above $54^{\circ} \mathrm{F}$ for Chinook salmon, but they found no published, peer-reviewed studies on the effects of temperature on Central Valley steelhead eggs and alevins. The thermal tolerance of juvenile Chinook to chronic elevated temperatures is believed to be approximately $75^{\circ} \mathrm{F}$, but no studies of this sort have been conducted on Central Valley steelhead.

Furthermore, no published data was available regarding the thermal tolerance of Central Valley Chinook to acute temperature elevation, which is dependent on the temperature to which a fish is first acclimatized, and such peer-reviewed data was also unavailable for Central Valley steelhead. The growth rate of juvenile Chinook salmon in the studies reviewed was optimal from $63^{\circ} \mathrm{F}$ to $68^{\circ} \mathrm{F}$, with slower growth outside of this range. Myrick and Cech (2005) studied the growth rates of juvenile steelhead obtained from Nimbus State Fish Hatchery at $52^{\circ} \mathrm{F}, 59^{\circ} \mathrm{F}$ and $66^{\circ} \mathrm{F}$. They found that the steelhead growth rates were highest at $66^{\circ} \mathrm{F}$, but 


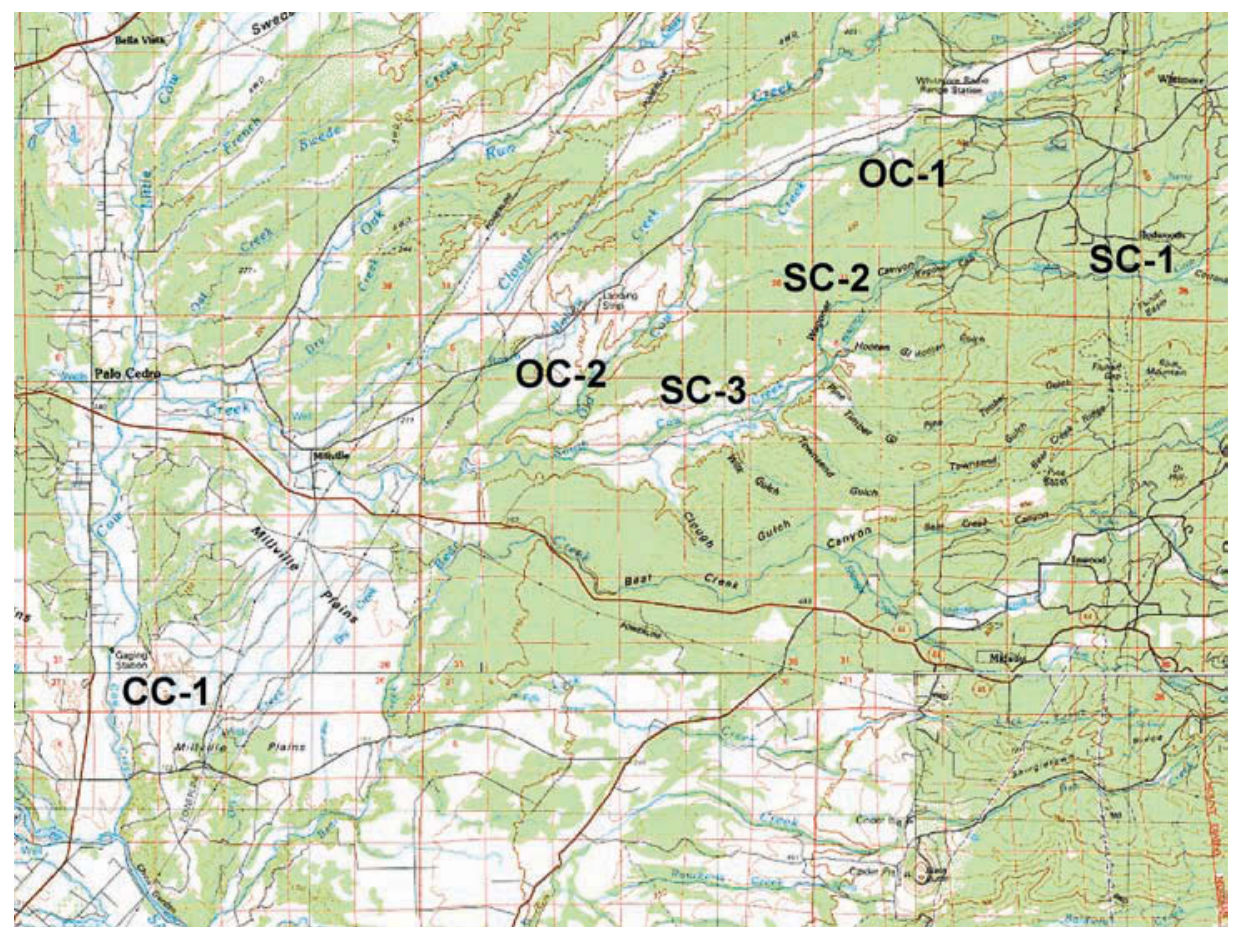

Fig. 1. Sampling sites on Old Cow Creek (OC-1, OC-2), South Cow Creek (SC-1, SC-2, SC-3) and the mainstem of Cow Creek (CC-1).

noted that the study did not test higher temperatures.

\section{Stream biodiversity and exotics}

Historically, native fish in Central Valley streams were distributed in a series of assemblages according to elevation (Moyle et al. 1998). Cold-water fish such as rainbow trout, riffle sculpin (Cottus gulosus) and speckled dace (Rhinichthys osculus) were found at mountain elevations (above approximately 1,800 feet) (Moyle 2002), and down into the upper foothills (approximately 1,200 feet). Fish such as California roach (Lavinia symmetricus) and hardhead minnow (Mylopharadon conocephalus) lived at foothill elevations (approximately 300 to 1,800 feet). Fish such as Sacramento suckers (Catostomus occidentalis) and Sacramento pikeminnow (Ptychocheilus grandis) appeared in the foothills, and were also present on the valley floor (approximately 0 to 300 feet). Species tolerant of warmer water, such as Sacramento perch (Archoplites interruptus) and splittail (Pogonichthys macrolepidotus) were present on the valley floor.

The introduction of nonnative fish species is a widespread phenomenon across the United States (Rahel 2000), including California streams. Introduced fish species in California tend to prey upon or compete with native species, frequently to the detriment of native populations, particularly in environments that have been modified to be warmer, slower flowing and more nutrient-rich than normal (Moyle 2002). The modification of stream water flow and habitat may affect the interaction between native and nonnative fish species. Moyle et al. (2003) assessed fish assemblages in the Cosumnes River and found that most nonnative species were in low-elevation, agricultural sections of the river, whereas native rainbow trout were mainly at higher elevation, higher gradient segments of the river. Apparently, nonnative species were intolerant of cooler waters with faster flows. Moyle et al. (2003) suggested that the management of water to provide increased flows and cooler water would benefit native species.

\section{Developing stream-specific data}

The development and implementation of successful best management practices (BMPs) to alleviate rangeland and irrigated pasture impacts on native fish and their habitat must be based upon a clear understanding of: (1) current habitat and fish assemblage conditions; (2) how environmental factors such as temperature determine fish distribution and habitat use; and (3) how management is modifying environmental factors. With this information, stake-

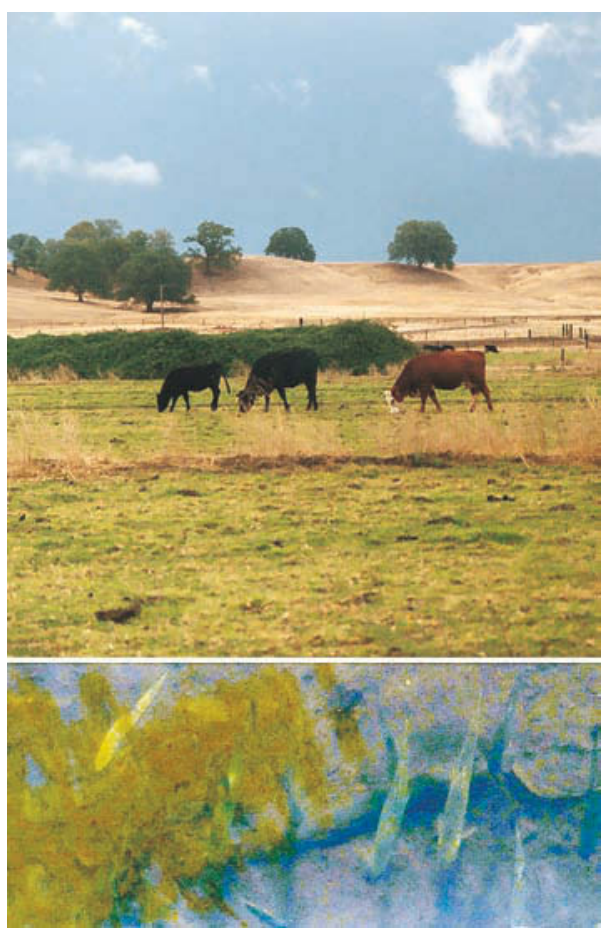

Top, cows graze near Cow Creek; above, trout in a pool in Old Cow Creek in midsummer.

holders can methodically assess streams of concern, identify priority stream reaches, examine current management practices potentially affecting priority reaches, and develop first approximations of BMPs to reduce impacts.

We utilized Cow Creek in Shasta County as an example of methodologies to develop region-specific information. We attempted to determine how different fish species were distributed along the length of the creeks from higher to lower elevation; whether preferred native species such as rainbow trout use pools; whether fish distribution and the use of pools change across the summer; whether pools stratify in terms of temperature and / or dissolved-oxygen concentrations; and how fish distribution relates to environmental factors such as temperature, flow, elevation and pool characteristics.

Location and data collection. We chose six pools in the Cow Creek drainage, at a range of elevations representative of rangeland habitat in this part of the Sacramento Valley (fig. 1). We sampled temperatures at each pool continuously from May through November, by placing two temperature loggers (Onset Optic Stowaway) near the bottom of each pool, and one temperature logger in the air (e.g., attached to a tree near the pool). We measured maximum 
depths to estimate the cover fish would find in a given pool, and length and width to allow estimates of pool area and fish density per pool. (Structures such as overhanging banks, boulders, logs and overhanging branches may also provide cover, but the measurement of these stream features was outside the scope of this study.)

We defined the upstream boundary of a pool as the point at which water cascaded in from a higher point, or where ripples ceased and the water became flat. The downstream end of the pool was defined as the point at which riffles started again. We sampled water flow, temperature and fish, monthly from June to October. Flow was measured at the downstream end of the pool, using a handheld flowmeter (Global Water FP101). During each monthly visit we used a handheld temperature and dissolved-oxygen probe (YSI 550A) to measure these variables at the surface, middepth and bottom of the pools. We did snorkel counts to estimate fish species present, density and age class. One snorkeler moved slowly through the pool, first working upstream along one bank, then floating down the middle, then upstream along the other bank and again down the middle. Fish observed during the second pass down the middle were assumed to be repeat counts, so they were only counted if a fish of a given species and size had not been seen in the pool up to that point.

Data analysis. We analyzed our data graphically and with regressionbased linear mixed-effects analysis (S-Plus version 6.1 software; Pinheiro and Bates 2000), in order to relate fish distribution and habitat use to environmental factors. Seven individual linear mixed-effects analyses were conducted to determine if there were statistically significant $(P<0.05)$ differences for the water temperature, pool depth and area, flow, and elevation of pools occupied by trout compared to pools not occupied by trout, between June and October. Linear mixed-effects analysis has distinct advantages for repeated-measures field studies such as this one, and has been used successfully to analyze other California stream data sets (Tate, Lile et al. 2005). Because we repeatedly sampled each site over the course of several months, there is a potential for codependence between observations made at each site at different times. The codependence introduced by repeated measurements of a single site through time can be efficiently addressed using a linear mixed-effects analysis.

\section{Pool characteristics}

The Cow Creek pools we studied ranged in elevation from 400 to 1,718 feet (table 1), and in surface area from 165 to 854 square yards. Maximum pool depth ranged from 3 to 7 feet, and usually occurred at the upstream end of the pool. Flows varied between pools and across the season, with lower elevation pools tending to have higher flows. None of the pools were stratified during our visits. Temperatures at the top and bottom of given pools showed differences of $0.10^{\circ} \mathrm{F}$ or less. Dissolvedoxygen concentrations were also similar at the top and bottom of each pool, giving further evidence that the pools were well mixed.

Dissolved-oxygen levels observed across the season ranged from 7.52 to 10.79 parts per million (ppm), well within the preferred ranged for sensi- tive fish such as salmonids (Bjornn and Reiser 1991); but this was expected, since we took our measurements at midday when aquatic plants produce oxygen. It is probable that dissolvedoxygen levels declined overnight, and were lowest just before dawn. An adequate supply of dissolved oxygen is important to fish, especially salmonids such as salmon and trout, during all stages of life (Bjornn and Reiser 1991; Brown 1985). The swimming ability of adult salmonids has been shown to decline at dissolved-oxygen levels less than 6.5 to 7.0 ppm. For spawning fish, dissolved-oxygen levels should reach at least $80 \%$ saturation with temporary levels no lower than $5.0 \mathrm{ppm}$. The growth rate of juvenile salmonids declines when dissolved-oxygen levels are below 5.0 ppm, and death occurs at less than 1.0 to 2.0 ppm of dissolved oxygen.

\section{Fish distribution in Cow Creek}

We observed fish in all pools from June to October 2003 (fig. 2a). The native fish species observed between the months of June and October were: California roach, Chinook salmon, rainbow trout/steelhead, Sacramento

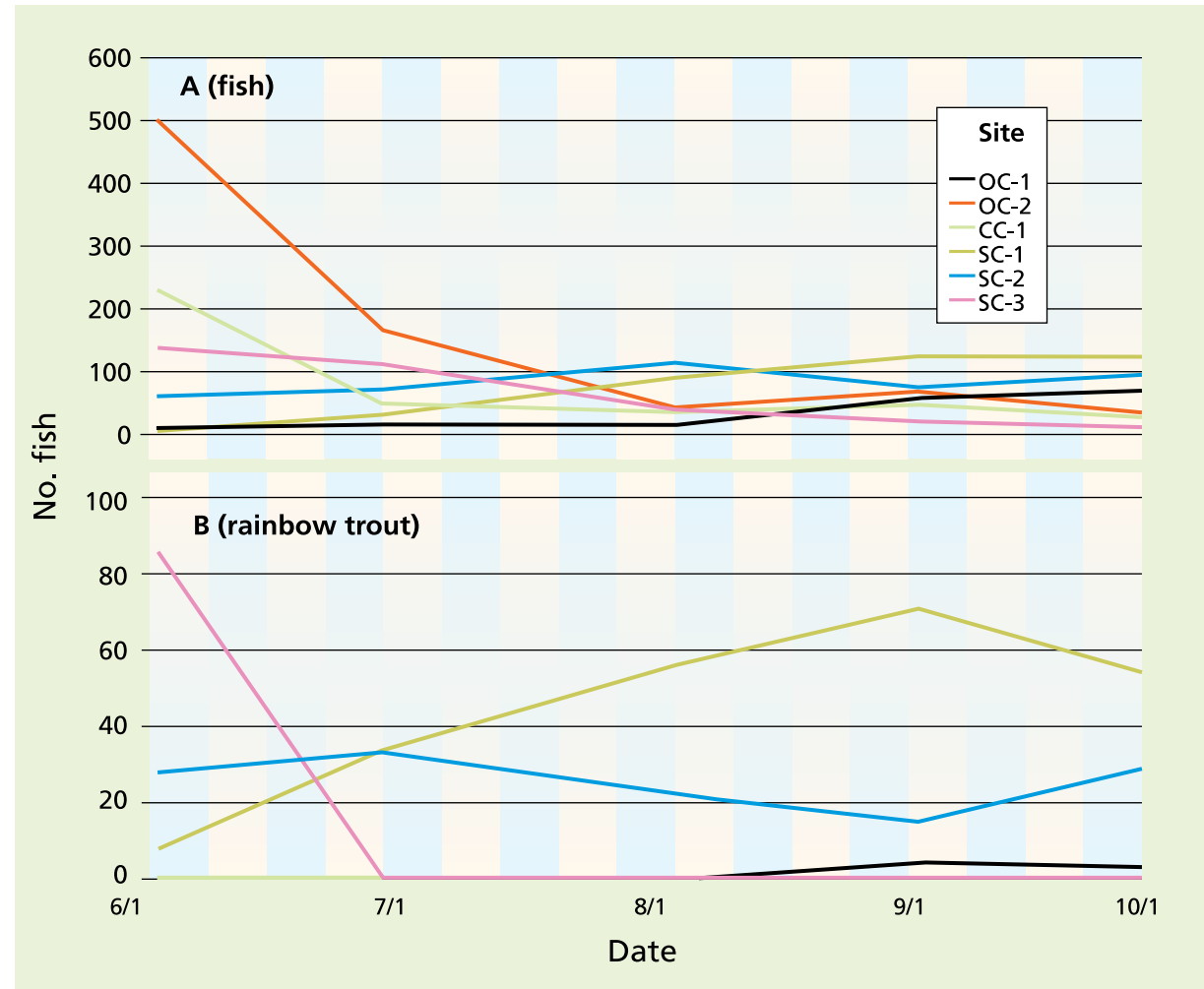

Fig. 2. Total number of (A) fish and (B) rainbow trout observed at six pools in tributaries of Cow Creek, 2003. 
pikeminnow, Sacramento sucker and speckled dace. Nonnative species observed were: green sunfish (Lepomis cyanellus), largemouth bass (Micropterus salmoides) and smallmouth bass (Micropterus dolomieu). Chinook salmon were observed only in the fall, during their upstream spawning migration, when most irrigation diversions had ceased. Since rainbow trout/steelhead are of great interest to fishery managers, and potentially of concern to landowners who use stream water for irrigation, we focused on rainbow trout/steelhead, and grouped the rest of the species together.

The declines in fish numbers between June and July reflect the mortality of large numbers of young-of-the-year fish, likely due to predation by birds or aquatic predators (fig. 2a). Rainbow trout/steelhead were observed in at least one pool in each of the sampling visits, including the hot summer months. Trout numbers increased in higher elevation pools as the season progressed (fig. 2b). Trout density was positively correlated with Julian day
TABLE 1. Characteristics of study pools in Cow Creek watershed

\begin{tabular}{lcccccc}
\hline \hline Pool & Elevation & Area & $\begin{array}{c}\text { Maximum } \\
\text { depth* }\end{array}$ & $\begin{array}{c}\text { Flow } \\
\text { min.-max. }\end{array}$ & $\begin{array}{c}\text { Temp. } \\
\text { stratificationt }\end{array}$ & Trout refugiał \\
\hline OC-1 & 1,331 & $y d^{2}$ & $f t$ & $c f s$ & ${ }^{\circ} F$ & \\
OC-2 & 568 & 339 & 4.0 & $4-155$ & -0.10 & Yes \\
SC-1 & 1,718 & 165 & 7.0 & $21-170$ & -0.01 & No \\
SC-2 & 1,053 & 227 & 4.5 & $29-141$ & -0.03 & Yes \\
SC-3 & 614 & 685 & 4.5 & $11-57$ & -0.08 & Yes \\
CC-1 & 402 & 303 & 3.0 & $32-136$ & -0.10 & No
\end{tabular}

* Maximum depth observed at lowest stream-flow conditions during study period.

† Temperature at bottom of pool minus temperature at top $\left({ }^{\circ} \mathrm{F}\right)$.

₹ At least one trout was observed in the pool during midsummer observation.
$(P=0.058)$ for the period from June to October. Young-of-the-year trout emerge from the gravel in early spring, and thereafter total trout densities may be expected to decline due to mortality. The increase in trout density in higher elevation pools may indicate that trout are moving upstream toward cooler waters, or out of riffles and into pools in search of depth (cover) or food. Trout were observed in midsummer (sample visits June 30 to Sept.2) in three pools (table 1). We considered these pools to be summer temperature refugia, although the pools did not stratify.

\section{A (growing season)}

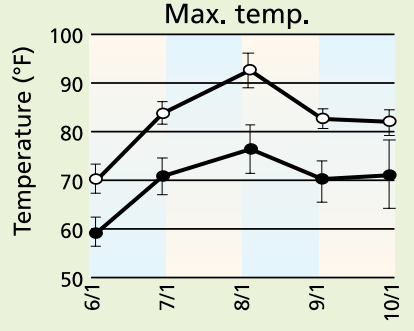

B (elevation)

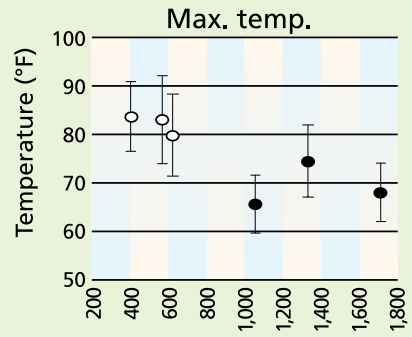

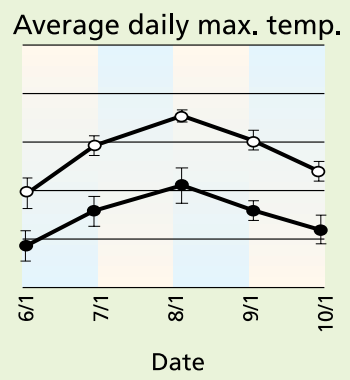

Average daily max. temp.

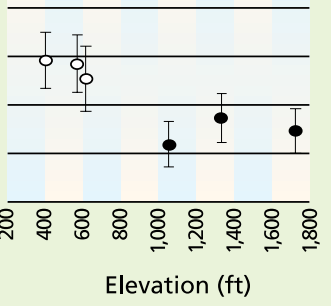

Average temp.

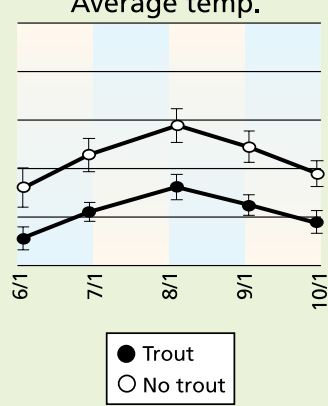

Average temp.

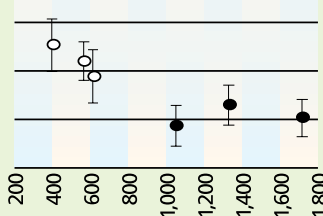

Fig. 3. Stream water temperature across (A) agricultural growing season and (B) elevation in pools in tributaries of Cow Creek, 2003. Values are grouped according to whether or not pools were occupied by rainbow trout in midsummer. Error bars are one standard deviation. Each point represents the average of five monthly samples (June to October) for one pool. Max. temp. is the highest temperature observed since the previous fish observation; average daily max. temp. is the average of the highest temperature observed each day since the previous fish observation; average temp. is the overall average temperature observed since the previous fish sampling.
Pools with trout in midsummer were cooler than pools without trout (fig. 3a, table 2). For example, the period maximum temperature for August in pools without trout in midsummer was over $90^{\circ} \mathrm{F}$, while in pools with trout it was well below $80^{\circ} \mathrm{F}$. This corresponds with the temperature tolerance value of $75^{\circ} \mathrm{F}$ for juvenile Chinook salmon. The period average temperature in pools with trout in midsummer was about $65^{\circ} \mathrm{F}$ in August, which corresponds to the optimal growth temperature ranges observed for juvenile Chinook salmon and steelhead.

Stream temperature was correlated with elevation (fig. 3b). Higher elevation pools were cooler and contained trout in midsummer. Pools that contained trout in midsummer contained only native fish species. Other pools contained a higher proportion of native species in spring and fall, when water temperatures were cooler.

Flows declined across the summer months, then began to increase in October (fig. 4). Flows were higher in pools with no midsummer trout, because these pools were farther downstream in the system where more tributaries, surface runoff and groundwater flow had joined the stream. This suggests that flow volume alone is not a good predictor of the presence of trout, and that other factors such as water temperature and dissolved oxygen should also be considered. In general, it is important to determine whether increased flows in lower pools reflects the return of potentially warm tailwater from irrigated pastures, a determination critical to BMP development and implementation.

For the sites on South Cow Creek and Cow Creek, water flow did not increase steadily with decreasing elevation (fig. 5). Throughout the season, 


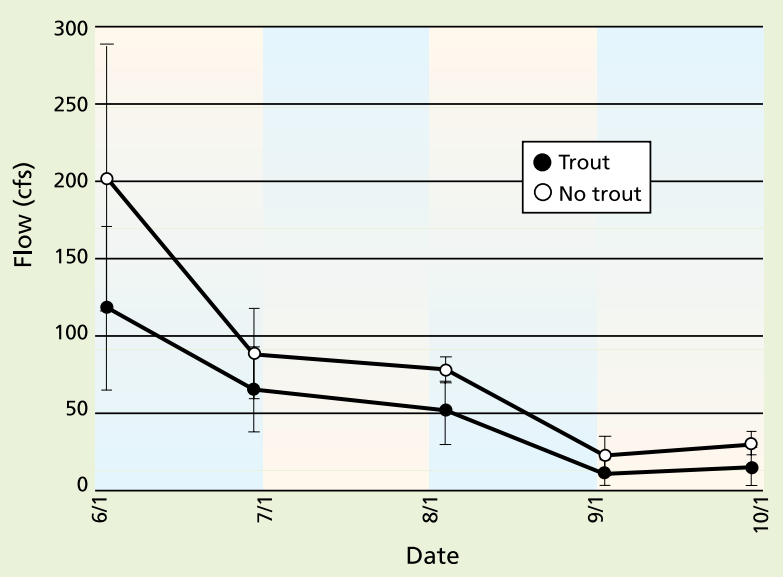

Fig. 4. Flow (cubic feet per second) across the agricultural growing season in tributaries of Cow Creek, 2003. Values are grouped according to whether or not pools were occupied by rainbow trout in midsummer.

flows at site SC-2 were lower than at site SC-1, which was farther upstream. This observation is due to the diversion of water from the mainstem of South Cow Creek between sites SC-1 and SC-2, for use at the Pacific Gas and Electric Company's (PG\&E) South Cow Creek Powerhouse. The water is returned to South Cow Creek between sites SC-2 and SC-3 via a PG\&E canal, restoring much of the creek's volume.

Linear mixed-effects statistical analysis was done on the full data set (i.e., six pools, with five monthly visits per pool between June and October). The resulting seven models indicated that the presence of trout was negatively correlated with temperature and positively correlated with pool depth, but not correlated with pool area, elevation

TABLE 2. Results of linear mixed-effects analysis to predict pool characteristics by the presence of trout

\begin{tabular}{llrr}
\hline \hline Pool characteristics & Model term & Coefficient (S.E.) & P value \\
\hline Max. temp. ( $\left.{ }^{\circ} \mathrm{F}\right)$ & Intercept & $82.13(2.07)$ & $<0.001$ \\
& Trout present & $-12.86(2.92)$ & 0.012 \\
Avg. daily max. temp. ( $\left.{ }^{\circ} \mathrm{F}\right)$ & Intercept & $77.60(1.43)$ & $<0.001$ \\
& Trout present & $-13.10(2.02)$ & 0.003 \\
Avg. temp. ( $\left.{ }^{\circ} \mathrm{F}\right)$ & Intercept & $72.13(1.59)$ & $<0.001$ \\
& Trout present & $-11.46(2.24)$ & 0.007 \\
Pool depth (ft) & Intercept & $-0.72(0.10)$ & $<0.001$ \\
& Trout present & $0.52(0.14)$ & 0.020 \\
Pool area (yd $\left.{ }^{2}\right)$ & Intercept & $273.56(70.12)$ & $<0.001$ \\
& Trout present & $-122.08(99.16)$ & 0.286 \\
Elevation (ft) & Intercept & $-300.56(72.30)$ & $<0.001$ \\
& Trout present & $133.68(102.25)$ & 0.261 \\
Flow (cfs) & Intercept & $84.00(19.46)$ & 0.002 \\
& Trout present & $-31.93(22.98)$ & 0.237 \\
\hline
\end{tabular}

* Significant coefficients for "trout present" model term are directly interpreted as the difference in pool characteristics for pools where trout are present compared to pools without trout (e.g., pools with trout averaged 0.52 feet deeper than pools without trout).

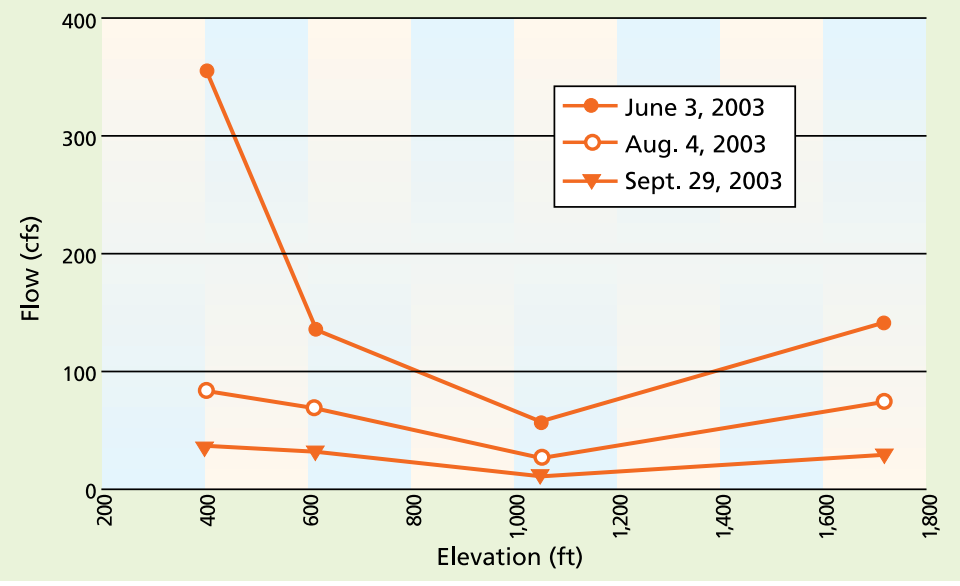

Fig. 5. Flow (cubic feet per second) and elevation on South Cow Creek and Cow Creek (SC-1, SC-2, SC-3, CC-1), June 3, Aug. 4 and Sept. 29, 2003. Flows at site SC-2 were consistently lower than flows at site SC-1, likely due to the diversion of water to the South Cow Creek Powerhouse upstream of site SC-2. or flow (table 2). The model term "trout present" in table 2 can be directly interpreted as the average difference of pools occupied by trout compared to unoccupied pools.

For example, the maximum daily temperature of pools occupied by trout was $12.86^{\circ} \mathrm{F}$ cooler than pools not occupied by trout. Conversely, pools occupied by trout were 0.52 feet deeper on average compared to unoccupied pools. Two relatively deep pools, OC-2 and CC-1, did not have trout in midsummer, likely because temperatures were too high (table 1).

\section{Fish and farm implications}

Our study looked at fish distribution in the Cow Creek watershed across the spring-summer-fall season, roughly correlated with the agricultural growing season and the use of stream water for irrigation. The results suggest that the distribution of fish species in pools in rangeland streams varies across the growing season, and is correlated with factors such as stream temperature and pool depth. Lower elevation pools may provide habitat for cold-water spe- cies such as rainbow trout/steelhead and salmon in spring and fall, but not in midsummer when pool temperatures increase. In contrast, higher elevation pools may provide cold-water fish habitat throughout the year. It is likely that rainbow trout/steelhead populations are limited by the stream area that is habitable in midsummer, and that lengthening the part of the stream that is cold enough year-round to support cold-water species will allow populations to increase.

Since species distribution is elastic over the season, the species observed in a given pool depends on the time chosen for sampling. This phenomenon may assist in the design of habitat monitoring and fishery restoration projects where funds are limited. Midsummer is likely to be the most efficient time of year to assess the abundance, size and age composition of resident rainbow trout populations and other cold-water native species, since cold-water fish are confined to cooler (generally higher elevation) areas.

Irrigation diversions may affect pool characteristics such as flow, maximum depth and temperature. If irrigation practices tend to cause stream water temperatures to increase, it may be possible to adjust agricultural water-use practices so that tailwater is no warmer than the stream water to which it is returned. It would then be possible to extend the length of the stream that is cool enough to be habitable for trout throughout the summer, and increase the minimum habitat area available. 


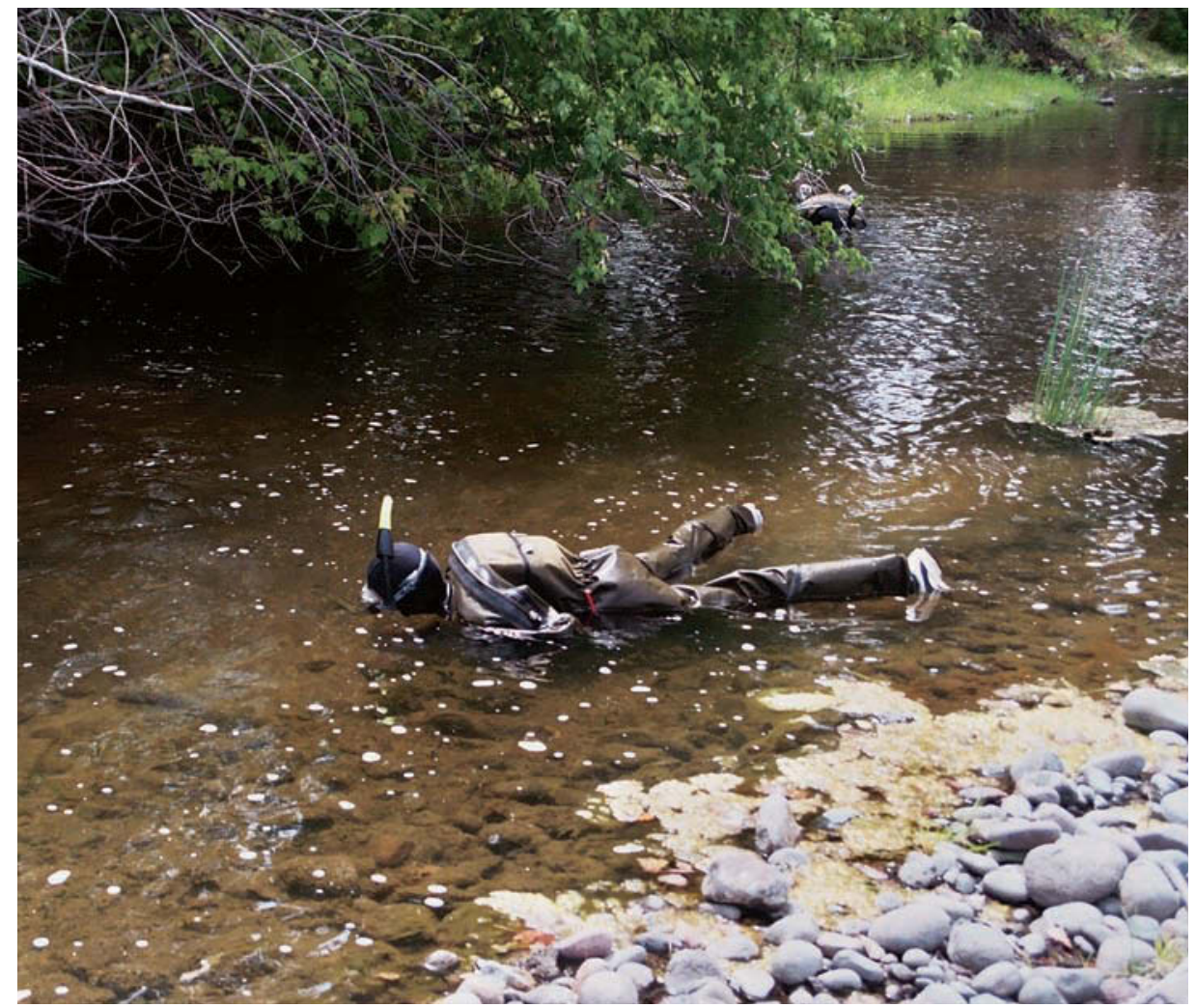

To spawn and thrive, fish have specific water temperature and flow requirements. Best management practices for irrigation can minimize adverse effects on stream habitat. Author Thompson snorkels in South Cow Creek to observe and count fish.

Preferably these management practices would be implemented without excessive costs to irrigators. Such practices would have the added benefit of reducing regulator concerns about the impacts of rangeland agricultural practices on streams and native fish.

This study provides a foundation for understanding the current conditions and relationships among stream habitat, fish distribution and habitat use, as they correspond to the period of agricultural irrigation-water extraction and return to Cow Creek. Fish habitat use and distribution is not static and is driven by factors (temperature and pool depth) that could logically be affected by stream-based irrigation diversion and return irrigation practices (Tate, Lile et al. 2005; Tate, Lancaster et al. 2005). The next focus of research on the potential linkage between irrigation management and habitat factors should be strategic stream temperature and flow monitoring of lower elevation pools. Tate, Lancaster et al. (2005) provide an example of such a monitoring strategy in similar streams in northeastern Modoc County. The results of the current study - and future studies to assess relationships between BMPs, stream temperature and flow - will allow more informed choices about which BMPs to implement and their prioritization. This should result in fewer adverse effects on stream habitat, and the avoidance of unwarranted impacts on agricultural stakeholders in the watershed.

L.C. Thompson is Assistant Specialist, Department of Wildlife, Fish, and Conservation Biology, UC Davis; L. Forero is County Director and Farm Advisor, UC Cooperative Extension, Shasta County; and Y. Sado is Postgraduate Researcher and K.W. Tate is Specialist, Department of Plant Sciences, UC Davis. The authors gratefully acknowledge the landowner cooperators in the Cow Creek watershed who gave access to their properties for this study; Mike Berry, California Department of Fish and

Game, for his advice on field protocols; and Peter $B$. Moyle and anonymous reviewers for reviewing the manuscript.

\section{References}

Beschta RL, Bilby RE, Brown GW, et al. 1987. Stream temperature and aquatic habitat. In: Salo EO, Cundy TW (eds.). Streamside Management: Forestry and Fishery
Interactions. University of Washington, Institute of Forest Resources. Contribution No. 57. p 191-32.

Bjornn TC, Reiser DW. 1991. Habitat requirements of salmonids in streams. Am Fish Soc Spec Pub 19:83-138.

Brown GW. 1985. Forestry and Water Quality. College of Forestry, Oregon State Univ Publ, Corvallis, OR. $142 \mathrm{p}$.

Ebersole JL, Liss WJ, Frissell CA. 2003. Thermal heterogeneity, stream channel morphology, and salmonid abundance in northeastern Oregon streams. Can J Fish Aquat Sci 60:1266-80.

Elliott JM. 2000. Pools as refugia for brown trout during two summer droughts: Trout responses to thermal and oxygen stress. J Fish Biol 56:938-48.

Harding JS, Benfield EF, Bolstad PV, et al. 1998. Stream biodiversity: The ghost of land use past. Proc Nat Acad Sci USA 95:14843-7.

Mihursky JA, Kennedy VS. 1967. Water temperature criteria to protect aquatic life. Am Fish Soc Spec Pub 4:20-32.

Moyle PB. 2002. Inland Fishes of California. Berkeley, CA: UC Pr. 502 p; fig. 5.

Moyle PB, Crain PK, Whitener K, Mount JF. 2003 Alien fishes in natural streams: Fish distribution, assemblage structure, and conservation in the Cosumnes River, California, U.S.A. Env Biol Fish 68:143-62.

Moyle PB, Marchetti MP, Baldrige J, Taylor TL. 1998. Fish health and diversity: Justifying flows for a California stream. Fisheries 23(7):6-15; fig. 2.

Myrick CA, Cech JJ Jr. 2004. Temperature effects on juvenile anadromous salmonids in California's central valley; What don't we know? Rev Fish Biol Fisheries 14:113-23.

Myrick CA, Cech JJ Jr. 2005. Effects of temperature on the growth, food consumption, and thermal tolerance of age-0 Nimbus-strain steelhead. N Am J Aquacult 67:324-30.

Nielsen JL, Lisle TE, Ozaki V. 1994. Thermally stratified pools and their use by steelhead in northern California streams. Trans Am Fish Soc 123:613-26.

Pinheiro JC, Bates DM. 2000. Mixed Effects Models in S and S-PLUS. New York: Springer-Verlag. $528 \mathrm{p}$.

Rahel FJ. 2000. Homogenization of fish faunas across the United States. Science 288:854-6.

Tate KW, Lancaster DL, Morrison, JA, et al. 2005. Monitoring helps reduce water-quality impacts in floodirrigated pastures. Cal Ag 59(3):168-75.

Tate KW, Lile DF, Lancaster DL, et al. 2005. Statistical analysis of monitoring data aids in prediction of stream temperature. Cal Ag 59(3):161-7.

Thompson LC, Larsen R. 2004. Fish Habitat in Freshwater Streams. Farm Water Quality Planning Series Reference Sheet 10.3. UC DANR Pub 8112. 12 p; table 1. http://anrcatalog.ucdavis.edu/merchant. ihtml? pid $=5632 \&$ step $=4$.

Walters CJ, Juanes F. 1993. Recruitment limitation as a consequence of natural selection for use of restricted feeding habitats and predation risk taking by juvenile fishes. Can J Fish Aquat Sci 50:2058-70.

Zoellick BW. 1999. Stream temperatures and the elevational distribution of redband trout in southwestern Idaho. Great Basin Naturalist 59:136-43. 